\title{
Fisheries Sector and the Marketing Structure in Turkey
}

\section{Kaygisiz F*}

Department of Animal Breeding and Husbandry, Istanbul University-Cerrahpasa, Turkey

*Corresponding author: Ferhan Kaygisiz, Istanbul University-Cerrahpasa,

Veterinary Faculty, Department of Animal Breeding and Husbandry, 34320, Istanbul, Turkey, Tel: +902124737070; Email: ferhan_64@yahoo.com

\section{Mini Review}

Volume 3 Issue 1

Received Date: February 14, 2019

Published Date: March 18, 2019

DOI: $10.23880 /$ ijoac- 16000161

\section{Abstract}

This study aims to reveal the current situation of the fisheries sector in Turkey together with its marketing structure and problems. One of the most important problems of the fisheries sector in Turkey is the marketing structure. The most intense used marketing channel is the fisher-commission agent-retailer-consumer marketing channel. The income of the fish breeder is low due to the small role of cooperatives in marketing.

Keywords: Turkey; Fisheries; Marketing; Problems

\section{Introduction}

Turkey has a strong potential for aquaculture. The fisheries sector is an important source of income and employment. The effective and sustainable use of these resources is highly important. The total seafood production in Turkey is 630820 tonnes [1]. With its current production, while Turkey 6th in Europe; it is in around 30s in the world [2]. Being $5.5 \mathrm{~kg}$ per capita in
Turkey, the average consumption is far below the world average of $19.2 \mathrm{~kg}$ [1].

\section{Current Status of Fisheries Sector}

Table 1 shows the amount of seafood production through hunting and cultivation, and the amount of import and export in between 2008-2017.

\begin{tabular}{|c|c|c|c|c|c|}
\hline Years & Hunting (Tonnes) & Cultivation (Tonnes) & Total Production & Import & Export \\
\hline 2008 & 494.124 & 152.186 & 646.310 & 63222 & 54526 \\
\hline 2009 & 464.462 & 158.729 & 623.191 & 72686 & 54354 \\
\hline 2010 & 485.939 & 167.141 & 653.080 & 80726 & 55109 \\
\hline 2011 & 514.755 & 188.790 & 703.545 & 65698 & 66738 \\
\hline 2012 & 432.442 & 212.410 & 644.852 & 65384 & 74006 \\
\hline 2013 & 374.121 & 233.394 & 607.515 & 67530 & 101063 \\
\hline 2014 & 302.212 & 235.133 & 537.345 & 77551 & 115381 \\
\hline 2015 & 431.907 & 240.334 & 672.241 & 110761 & 121053 \\
\hline 2016 & 335.320 & 253.395 & 588.715 & 82074 & 145469 \\
\hline 2017 & 354.318 & 276.502 & 630.820 & 100444 & 156681 \\
\hline
\end{tabular}

Table 1: Turkey Seafood Production, İmport and Export (tonnes). 


\section{International Journal of Oceanography \& Aquaculture}

The amount of production provided by hunting has decreased in recent years. In the period from 2008 to 2017 in Turkey, a 29\% reduction in hunting has taken place; it has been an $81 \%$ growth in the cultivation field. As for total production, it has decreased by $2.5 \%$. The decrease in the production through hunting has been struggled to be met by production through cultivation. On the one hand, this depends on the decrease in our fish stocks but on the other hand, it depends on the support given to the cultivation [2]. Imports and exports increased during the same period. In 2017 in contrast to the export amounted to 854.731.829 TL, import has taken place amounted to 841.383.610 TL [1]. Turkey is a country which both imports and exports in terms of seafood. Income received from exports was higher than import expenditures. Fish consumption per capita decreased from $7.8 \mathrm{~kg}$ down to $5.5 \mathrm{~kg}$ in the period of 2008-2017 [1].

\section{Fishing Marketing Channels}

Considering the seafood distribution system in Turkey, it is noticed that marketing activities are carried out through four channels: (1) directly shipping to fish marketplace, (2) directly shipping from the boat to the commission agent, (3) shipping to the processing facility and (4) shipping to the cold storage depot in the name of the boat. There are 13 aquaculture warehouses in our country. Approximately 200-300 thousand tonnes of aquaculture are sold in warehouses annually. In the aquaculture distribution system, fisheries warehouses are very important centers in terms of both providing the necessary data for fisheries management and controlling the criteria as the origin of sold products, hunting area and size bans, freshness, hygiene and food safety [3].

Marketing channels differ by products. In aquaculture, a multi-staged structure draws attention in the form of fishermen (producer)-fisheries warehouse commission agent (wholesaler or semi-wholesaler)-retailer-consumer. In the provinces where there is a fisheries marketplace, the caught fish are gathered in marketplaces, they are sold to retailers through commission agents after the vendue (auction) organized here. While some of the commission agents work as wholesalers, some continue as a semi-wholesaler or retailer in the meantime [4].

One of the most important problems in fish marketing is the lack of organization of fishers. For this reason, the bargaining power of fishers is weak and their effects on price formation are too low. Fishers are obliged to accept prices determined by commission agents. The fact that there are too many producers in this situation induces to a decrease in competition in marketing. The fact that fish meal-oil factories and commission agents, which are active in marketing, determine price negotiating among themselves both prevents competition and causes a reduction in fishers' income [5]. Direct sales through cooperatives will be beneficial to producer and consumer. Cooperatives will increase marketing effectiveness and shorten the marketing chain.

Considering business administration, cooperatives are ambidextrously highly important in terms of organization of producer and marketing, product evaluation and marketing along with production phase. Therefore, aquaculture cooperatives should play an important role in the evaluation and processing of products, provision of cheap and high-quality feed, provision of seed fish and solution of problems in marketing [6]. An effective and producer-oriented marketing system will benefit the fisher as well as the sector. A stable environment can be achieved for producers by means of resource management, price formation, and supply-demand balance via cooperatives [7]. Other problems in marketing are stated as the high rates in commission agent cuts and value-added tax, insufficient government support, difficulty in obtaining finance, costly hunting equipment [8].

For an increase in the efficiency of production and marketing, organizations in the form of cooperative should be supported and their effectiveness in marketing should be increased. As long as problems solved, profitability in fisheries industry and the contribution of the fisheries sector to Turkey's economy will increase.

\section{References}

1. TMFAL (2018) (Republic of Turkey Ministry of Food, Agriculture and Livestock) Fisheries Statistics.

2. Sarı̈zkan S (2016) Fisheries Sector and Economics in Turkey. Turkish Journal of Aquatic Sciences 31: 1522.

3. Ylldırım BR, Akyol O (2012) Izmir Wholesale Fish Market: Current Status, Fish Amounts (2007-2011) and Problems. Ege Journal of Fisheries and Aquatic Sciences 29(4): 151-155.

4. Güngör G, Benli K, Güngör H (2012) Marketing Seafood Products in Marmara Sea: A case study along the Coastal Strip in istanbul Province. Tekirdağ Ziraat Fakültesi Dergisi 9(2): 98-108. 


\section{International Journal of Oceanography \& Aquaculture}

5. Dağtekin M (2010) Fishery production and marketing structure in Trabzon (MSc Thesis). Çukurova University, Adana, Turkey.

6. Kocaman EM, Aydın A, Ayık Ö (2002) Structural and Economical analysis of trout farms in Erzurum city. EU J Fisheries \& Aquatic Sci 19(3-4): 319-327.
7. TDM (2014) (Turkish Ministry of Development) Special Commission Report on Fisheries.

8. Kaygisiz F, Eken M (2018) A Research on Determination of Fish Marketing Margins in Istanbul Province of Turkey. Turkish Journal of Fisheries and Aquatic Sciences 18: 801-807. 